\title{
Corporate Governance Practices and Audit Quality: Do They Matter for the Cost of Debt?
}

\author{
Sami Bacha \\ FSEG and LAMIDED, University of Sousse, Sousse, Tunisia \\ Email: samybacha@hotmail.com
}

How to cite this paper: Bacha, S. (2019) Corporate Governance Practices and Audit Quality: Do They Matter for the Cost of Debt?. Theoretical Economics Letters, 9, 2262-2282.

https://doi.org/10.4236/tel.2019.97143

Received: August 7, 2019

Accepted: September 14, 2019

Published: September 17, 2019

Copyright () 2019 by author(s) and Scientific Research Publishing Inc. This work is licensed under the Creative Commons Attribution International License (CC BY 4.0).

http://creativecommons.org/licenses/by/4.0/ (c) (i) Open Access

\begin{abstract}
This paper sheds light on the effect of corporate governance practices and audit quality on the cost of debt. Particularly, we investigate the effect of the ownership structure and the audit committee independance, as well as the reputation of the external auditor, on the cost of debt. Based on a sample of Tunisian listed companies over the period 2007 to 2016 and using OLS regression models estimated with robust standard errors, our findings show that the cost of debt is inversely related to the director board size and the ownership concentration. Tunisian debtholders favour monitoring mechanisms that are likely to limit managerial opportunism and consider board monitoring effectiveness and the presence of blockholders as a source of greater assurance. The results also reveal evidence of a debt pricing effect of audit quality as measured by auditor size (Big4). The findings report, however, that the board composition and the presence of managerial shareholders, as well as the independence of audit committee have non-significant effect on the cost of debt.
\end{abstract}

\section{Keywords}

Corporate Governance, Audit Quality, Cost of Debt, Ownership Structure, Audit Committee

\section{Introduction}

The agency theory attests that the lenders may support a double risk linked to the shareholders expropriation behavior and the misappropriation by the company of a part of the investment earnings. Unlike shareholders, debtholders have no effective control on the use of the funds they provide. These funds can then be used opportunistically by corporate managers to achieve their own interest or these of shareholders. Because information is asymmetrical, external financing is 
more costly than internal free cash flows of investments. Indeed, debtholders are demanding a higher cost debt to cover potential default risks.

Several researches have highlighted the role of corporate governance in increasing performance or reducing cost of capital [1] [2] and [3]. The authors showed that the quality of corporate governance is likely to mitigate the debtholder's risk, reducing therefore the cost of debt capital. One of the major benefits arising from stronger corporate governance is the growing availability of funding and access to cheaper sources of funds [4]. Bhojraj and Sengupta [5] add that companies with stronger corporate governance can get low cost debt by reducing default risk due to the reduced agency problems and improved monitoring of managerial actions. Anderson, Mansi and Reeb [4] find that the cost of debt financing of American companies is inversely related to the board independence, board size, as well as to audit committee independence, size and meeting frequency. They conclude that the bondholders consider the board and audit committee's monitoring effectiveness as a source of greater insurance with respect to the integrity of accounting and financial numbers. Feki and Khoufi [6] also find that young members and independents boards allow a better financial information quality, lowering thus the cost of debt of French listed companies. These results were confirmed for companies listed in Tehran Stock Exchange [7] and in Muscat Securities Market [8]. Moreover, Ghouma, Ben-Nasr and Yana [9] argue that the quality of the board composition/structure as well as the disclosure quality reduces the cost of bond financing in Canada. Adam, Mukhtaruddin, Soraya and Yusrianti [10] show, however, that the variables of Good Corporate Governance partially and simultaneously do not have a significant effect on the cost of debt of Indonesian listed companies.

Besides the corporate governance practices, other studies focus on the effect of the accounting information quality on the ex ante cost of debt [11]. The authors point out that financial institutions need to rely on alternative information sources, when assessing the borrowing firms' credit risk and monitoring debt contracts. Quality auditors may play then an important role in mitigating information asymmetry between management and creditors through an increased credibility of financial information [12]. This implies less information uncertainty and debt monitoring costs faced by banks and thus lower cost of debt. In line with these findings, Piot and Janin [13] argue that the leverage level may, in certain circumstances, influence the choice of auditor size or the presence of effective audit committee.

This study shed the light on the effect of corporate governance on the cost of debt of Tunisian listed companies. We contribute to the literature on corporate governance and cost of debt in several ways. First, we focus jointly on variables with a direct influence on the information asymmetries between debtors and creditors and having a significant impact on the cost of debt. We not only investigate the effect of corporate governance features such as board of directors characteristics and ownership types, but also the relevance of financial information resulting from the use of qualified auditor and the independence of audit com- 
mittee. Particularly, we focus on the characteristics of the director boards and the ownership structure, as well as the reputation of the external auditor. Second, we examine the corporate governance/cost debt link in emerging market such Tunisian setting where financial institutions play a critical role in financing firms' activities and where audit quality substitutes for conventional corporate control mechanisms such as boards of directors. Unlike studies conducted in developed countries, the corporate governance issue becomes very interesting in the Tunsian market characterized by low legal enforcement and a low level of corporate disclosure. Third, we help banks and debtholders to better assess the risks of the firms through their corporate governance effectiveness and audit quality. This study drives Tunisian authorities to improve the effectiveness of the corporate governance mechanism to reduce the rente expropriation and opacity risk. It also encourages managers to consider the audit quality as a means to lessen the information asymmetry and improve the financial information reliability.

Based on a sample of companies listed in Tunisian Stock Exchange (TSE) over the period from 2006 to 2016, we use OLS regression method to examine the effect of governance mechanism effectiveness and audit quality on the exante cost of debt. As an emergent market, the Tunisian regulatory authorities regulate only the bond market. Several new reforms were made to enhance corporate transparency and protect debtholders and creditors, whose interests depend not on financial information quality but also on managers' opportunism. Corporate governance and audit quality are respectively estimated using characteristics of board of directors, ownership structure and auditor type (Big 4 versus non-Big 4 auditors). The results show that banks and other financial institutions play a crucial role in financing the Tunisian companies. The findings attest that these debtholders are not very involved in corporate governance structures such as directors boards but they grant a great importance to the board size, the presence of block holders and the auditor type. The results show that the cost of debt is inversely related to the director board characteristics and the external auditor choice. However, they report non significant relation between the cost of debt and the ownership type.

This paper is organized as follow. Section 2 hereafter develops the theoretical framework and the hypotheses. Section 3 presents the research design. Section 4 discusses empirical results, while Section 5 concludes the paper.

\section{Literature Review and Hypotheses}

The literature on the determinants of the cost of capital generally documents a positive association between the firm risk measures and the cost of debt capital [1] [14] and [15]. The existence of agency conflicts supports to the lenders a double risk. The first one is the shareholders' expropriation behavior. The second is the misappropriation by the company of a part of the investment earnings. Unlike shareholders, debtholders have no effective control on the use 
of the funds they provide. These funds can then be used opportunistically by corporate managers to achieve their own interest or these of shareholders. For these reasons, lenders are demanding a higher cost debt. [11] document that because information is asymmetrical, external financing is more costly than internal free cash flows of investments. Diamond and Verrecchia [14] provide also evidence that firms with high credit risk incur very high costs.

Given the existence of agency costs which may be detrimental to capital providers and their interests, it is important to establish effective governance mechanisms by providing high quality of financial information. Diamond and Verrecchia [14] argue that the transparency of financial reporting reduces information asymmetry and increases investor demand for shares, which, by the way, improves the firm's liquidity and reduces its financing cost. This last result is related to the reduction of bid-ask spreads and the improvement of the transaction volumes and the reduction of the volatility of the stock return.

Prior research have shown a strong relationship between corporate governance and financial information quality [16] and [17]. The corporate governance concept looks for the achievement of such core values, as transparency and equity. Thus, the accounting and financial system appears to play an important role in balancing agency relationships [18]. Its major role lies in producing credible information likely to facilitate the managers' control and the effective implementation of shareholders' rights. Besides, Petra [16] and Elmagrhi et al. [18] argue that the corporate governance covers also the methods by which suppliers of finance control managers in order to ensure that their capital cannot be mismanaged and that they earn a return on their investment.

\subsection{Corporate Governance Practices and Cost of Debt}

The role of corporate governance in increasing performance or reducing cost of capital has been the subject of many studies. Emphasis was placed on specific governance mechanisms such as board characteristics [19], concentrated shareholding [16] and director shareholding [20].

\subsubsection{Director Board Characteristics and Cost of Debt}

The board constitutes a major control mechanism exhaustively discussed on corporate governance-related research. Allegrini and Greco [21] note that the board's principal functions consist mainly in evaluating decisions along with controlling executives. [4] also add that the board size, characteristics and composition have significant effect on its roles' effectiveness.

Klein [22] documents that the independent board mitigates the earnings management. In the same line, Samaha, Khlif, and Hussainey [23] advance that the information quality increases with the percentage of outside directors. Similarly, Beekes, Pope, and Young [24] notice that the board independence allows disclosing information of good quality by the firms in the United Kingdom. In line with these findings, Feki and Khoufi [6] show that young members and independents boards allow a better financial information quality. In other con- 
texts, Firth, Fung, and Rui [25] indicate that the presence of independent directors improves the earnings quality of Chinese firms. Dimitropoulos and Asteriou [26] confirm this finding for a sample of Greek firms.

Furthermore, Badertscher et al. [27] show that companies with more independent board structure and more effective board approach have more market liquidity compared to other companies. In fact, companies with higher score in terms of corporate governance quality experience lower ask-bid spread and higher different share supplied and demanded.

Hence, we may expect that:

$\mathrm{H}_{1}$ : The presence of independent board director lessens the agency conflicts, reducing then the cost of debt.

Other studies suggest that the independent directors are not enough competent to control the managers and their presence in the board has no effect on the reporting quality [19] and [16]. These authors underline that the size of the board of directors can also be associated with a good quality of financial reporting. In this line, some studies have indicated that the smaller boards are more efficient due to better director-to-staff communication, as well as smaller firms being easier to manage [25] and [23]. According to these studies, the optimal size for a board should not be more than nine. A reduced number of directors imply high degree of coordination and communication between them and the managers [22]. Indeed, Bradbury, Mak, and Tan [19] found that large board size reduces the information content of incomes and increases the earnings management. Beekes, Pope, and Young [24] note, however, that the high number of directors ensures the value relevance of financial statements. A director's board of a large size is likely to increase relevant experience, promote expertise and, consequently, the level of voluntary information disclosure. Samaha, Khlif, and Hussainey [23] also report that firms with large boards are more likely to disclose a greater deal of corporate governance information than their smaller board counterparts. More recently, Allegrini and Greco [21] document that larger boards usually tend to disclose more information about firms' strategic objectives than smaller ones. As for Dimitropoulos and Asteriou [26], they have concluded that large boards are more efficient than small ones in monitoring and controlling the financial communication quality. Hence, when number of board members is higher, the control capacity and performance would be enhanced.

$\mathrm{H}_{2}$ : The board size enhances the control capacity, reducing thereby the cost of debt.

\subsubsection{Ownership Structure and Cost of Debt}

Furthermore, the theoretical and empirical studies about corporate governance have suggested that the ownership structure is a crucial determinant of the governance practices effectiveness [28] and [27]. According to Shleifer and Vishny [28], ownership concentration increases control over managers. Moreover, Firth, Fung and Rui [25] claim that monitoring with large shareholders helped in ac- 
cessing private, valuable and important information. When large shareholders are also board members they can affect management especially in companies with concentrated ownership. In this line, Shleifer, and Vishny [28] and Jensen and Meckling [29] point out that blockholders may curb the discretionary behavior of the managers, incite them to adopt profitable strategies and disclose relevant and reliable information. Moreover, Klein [22] and Beekes, Pope and Young [24] report that the ownership concentration reduces the earnings management which improves the financial disclosure quality. Similarly, Petra [16] argues that the concentrated ownership decreases the level of discretionary accruals and increases the voluntary disclosures made by managers.

Other research, however, have documented negative relationship between ownership concentration and the level of discretionary [30] and [31]. They argued that the presence of controlling shareholders may exacerbate the agency problems. Indeed, holding a large fraction of capital may incite shareholders to be entrenched in the firm and to expropriate the other shareholders [17]. Similarly, many studies advance that concentrated ownership reduces the relevance of the financial information and alters the credibility of the accounting numbers [19]. Finally, Firth, Fung and Rui [25] report that ownership concentration affects negatively the earnings quality.

As Tunisian firms are mostly controlled by family and institutional shareholders, and investors are poorly protected, ownership concentration seems to be not useful for monitoring the management-taken accounting decisions, denoting then a higher earnings quality. Increased concentration may exacerbate the rent expropriation and the level of discretionary accruals. Thus, we assume that:

$\mathrm{H}_{3}$ : Ownership concentration may weaken the monitoring mechanisms, increasing therefore the cost of debt.

Further studies have shown that institutional investors emerges as a critical factor that is supposed to improve corporate control efficiency [5] and [32]. The authors explain that institutional investors are more able to monitor firms and may greatly help in improving corporate governance disclosure. Moreover, Jiambalvo et al. [33] and Aggarwal et al. [32] note that a positive relationship is reckoned to persist between institutional ownership and voluntary corporate disclosure. Empirical studies show that firms with higher institutional ownership have more efficient corporate governance practices [32]. They also establish a negative or non-significant association between institutional investors and earning management. However, Firth, Fung and Rui [25] discern that the presence of the major shareholders who may be financial or state institutions and foreigners entails poor quality of financial information.

Generally, the presence of higher institutional ownership is discovered to yield a positive impact on information transparency, as managers would be discouraged from undertaking earning management. Thus, the fourth hypothesis is:

$\mathrm{H}_{4}$ : Institutional investors may improve the corporate control efficiency, lo- 
wering thus the cost of debt.

The work of Jensen and Meckling [29] has pointed out the potential conflict of interest between corporate managers and dispersed shareholders, when managers do not have an ownership interest in the firm. Managers have the natural tendency to allocate the firm's resources in their own best interests, which may conflict with the interests of outside shareholders. Jensen and Meckling [29] also note that inside shareholder is able to augment this stream of cash flows by consuming additional nonmarketable perquisites. They explained that there is an incentive for the manager to adopt investment and financing policies that benefit him, but reduce the payoff to outside stockholders.

However, as management's equity ownership increases, their interests are likely to coincide more closely with those of outside shareholders. Managerial concentration ownership constitutes then an internal governance mechanism, which alleviate the agency conflicts between managers and shareholders [29].

In line with this view, Ballesta and Meca [20] highlighted a positive association between managerial ownership and corporate performance. Accordingly, higher management's equity ownership leads to an alignment effect of interest, maximizing thus the corporate value. Moreover, Badertscher et al. [27] argue that when equity ownership and corporate decision-making are concentrated in just a small number of decision-makers, these owner-managers will likely be more risk averse and thus less willing to invest in risky projects.

Florackis and Kostakis [34] point out, however, that when managerial ownership is higher, managers will have enough voting power to safeguard their positions regardless of their achievement performance. This can reduce the value of the firm and increases the amplification of information asymmetry.

Consequently, we predict that firms with greater managerial ownership concentration are more risk averse and less tempted to react opportunistically. Managerial ownership tends to moderate the agency conflicts by acting in the best interest of their shareholders and debtholders. Hence, we assume that:

$\mathrm{H}_{5}$ : Managerial ownership may moderate the agency conflicts, lowering thus the cost of debt.

\subsubsection{Audit Committee Independence and Cost of Debt}

Another internal governance mechanism on which researchers have focused is the presence of an audit committee. Allegrini and Greco [21] find that audit committee helps in implementing corporate governance standards. Piot and Janin [13] argue that the role of audit committee is to improve disclosure quality and reduce asymmetric information. Indeed, monitoring function by audit team drives the management team to maintain financial information as scheduled [35]. Zgarni and Khamoussi [36] note that the audit committee plays an important role in assessing and reviewing external and internal information, ensuring financial reporting, providing control system and monitoring the connection between the external auditor and management. Hence, the presence of an audit committee is closely associated with a reliable financial communication transpa- 
rency, for instance, reducing the incidence of error irregularities [37]. Indeed, Zgarni and Khamoussi [36] predict that the presence of an audit committee can lead to a noticeable reduction in information variations, by sending a signal to the market showing the company's commitment to good corporate governance practices. In extend to these findings. Chen et al. [35] attest that the presence of an audit committee participates significantly in reducing the earning management practices. As regards to the French context, Piot and Janin [13] revealed that the presence of an audit committee within the board entices the CEO to engage in earning management practices. In the same line, Bradbury, Mak and Tan [19] and Tepalagul and Lin [38] found that the degree of independence ensures good corporate governance practices. In fact, having a financial stake in a company makes audit committee members less impartial and their independence questionable. Consequently, the audit committee member has to be independent to improve the probability of auditors' issuing going-concern opinions and is related to a decline in the probability of auditor expulsion taking after going-concern opinions [36]. Hence, audit committee independence provides an authoritative impact and has more power. Several commissions and reports, such as the Cadbury report [39] or the Blue Ribbon Committee [40] recommended that the audit committee have to be composed of at least three outside non-executive directors to assure its independence.

As a result, the presence of a base number of non-executive directors within the audit committee expresses the firm's commitment to improve its governance mechanism effectiveness.

So, we assume that:

$\mathrm{H}_{6}$ : The presence of an independent audit committee proves the company's commitment to good corporate governance practices, which may lower the cost of debt.

\subsection{External Audit Quality and Cost of Debt}

Previous auditing studies highlighted the usefulness of external audit services in mitigating the agency problems in companies [13] [41] and [36]. The agency theory view attests that the external audit can be an effective control mechanism to monitor the managers and guarantee the integrity of financial reports [29] and [42]. In this line, DeAngelo [41] argues that the appointment of an independent external auditor can reduce the probability of earnings manipulation by lessening the managerial opportunism. Moreover, Pittman and Fortin [12] note that the quality auditors may play an important role in mitigating information asymmetry between management and creditors through an increased credibility of financial information. Indeed, in debt economy, financial institutions need to rely on alternative information sources, when assessing the borrowing firms' credit risk and monitoring debt contracts. This, in turn, implies less information uncertainty and debt monitoring costs faced by banks and thus lower cost of debt [43]. 
Previous research has provided evidence supporting the positive effect of the audit firm size on audit quality. DeAngelos [41] notes that audit firm size is the most commonly used criterion of audit quality. He argues that audit quality is not independent of audit firm size and that higher-quality auditors are more likely to improve accounting controls and detect accounting irregularities due to greater knowledge and skills. Moreover, Tepalagul and Lin [38] and Kim, Chung and Firth [44] suggest that larger auditors, commonly named Big 4, are expected to have more incentives to preserve their independence and provide high-quality audit services to maintain their reputation and enlarge their portfolio. In practice, the auditor reputation or quality is apprehended by his belonging to the major audit firms named BIG 4 [45]. Several authors advocate that Big 4 audit firms provide superior audit since they enjoy quality robust training programs, standardized audit methodologies, and more industry specialization and knowledge to detect problems related to companies' financial reporting policy. Indeed, the large and well-established renowned audit firms usually have a great reputation to preserve and maintain, so they would tend to resort to more disclosers so as to safeguard their established positions [37] and to reduce their legal liability. In this line, Kim, Chung and Firth [44] have concluded that quality auditors most often tend to reduce earnings management, thus improving the financial information quality. Moreover, Big 4 auditors are associated with an increased probability of issuing modified audit reports and more informative signals of financial distress for creditors [12].

All in all, audit firm size and higher-quality auditors may improve the perceived audit quality by creditors, which in turn leads to lower information asymmetry between managers and creditors and reduced monitoring costs in debt contracts, implying a lower cost of debt.

Thus, we assume that:

$\mathrm{H}_{7}$ : Big 4 auditor tends to improve the financial information quality, reducing then the cost of debt.

\section{Research Design}

\subsection{Sample Selection and Data Collection}

We employ a sample of firms listed in Tunisian Stock Exchange (TSE) over the period 2007 to 2016 and use OLS regression model estimated with robust standard errors. We focus specifically on this period for two main reasons. First, since 2007 Tunisian financial authorities began a reform program aiming to improve the governance mechanism as solution to the problems of information transparency published by companies. Several new rules were promulgated related to the board structure, its functioning, the presence of independent members, the presence of an audit committee and furthermore the independence of board directors. Second, this period covers a series of firm's bankruptcy linked to governance mechanisms ineffectiveness and financial reporting quality. As a result, Tunisian financial authorities adopt a new law to enhance corporate go- 
vernance transparency and audit quality [47].

Financial and accounting data were extracted from the financial statements of listed companies available on the TSE and Financial Market Council websites. Corporate governance data (Ownership structure, director board characteristics and audit committee) were hand collected from the annual reports of listed companies. We exclude banks, insurance companies, leasing, investment and factoring companies. These companies exhibit a particular behavior regarding to corporate governance and apply a specific accounting regulation. The final sample includes 290 firm-year observations and covers three sectors of activity: industry sector (vehicle's components, IT manufacturers, telecommunication, building, food-processing, household products, medical biology), services and trading (distribution).

\subsection{Corporate Governance Measurements}

We consider several variables that are related to the board of directors (composition and size), the ownership structure (ownership concentration, presence of institutional shareholder and managerial ownership) and the audit quality.

In the Tunisian context, the board usually contains other types of directors (in addition to outside members) who represent the major shareholders, the families, the State, the financial institutions and the foreigners. The presence of these directors can be seen as an effective governance mechanism since they can monitor the managers and incite them to improve the financial reporting quality. However, they may have incentives to take advantage of asymmetric information, especially when they hold a large fraction of the shares which may alter the information quality. Thus, we include in our study the identity of the directors and the presence of independent audit committee.

Therefore, we obtain a large number of governance variables that represent the main mechanisms of control of Tunisian firms. The first factorial axis is associated with the board directors size (BDSIZE) and the presence of independent directors (BDIND). Bradbury, Mak, and Tan [19] and Klein [22] suggest that larger boards provide less individual assignments, and thus more extensive monitoring possibilities. Firth, Fung and Rui [25] consider the outsider or independent member the director who is neither manager nor shareholder in the company.

The second factor is related to the ownership concentration, which represents the intensity of control in a firm by large shareholders who detains more than $50 \%$ of the firm's equity (BlOCK). We consider also the managerial shareholders (MANAG) which represents the percentage of managers owning shares in the company, participate in strategy pattern and decision-making and who are almost present in the management board. This measure has been used previously by [27] and [34]. Finally, the presence of an institutional shareholder (INSTIT) is captured by the percentage of directors who represent the State and the financial institutions and their shareholding [32]. 
The third factor concerns the presence of audit committee, the independence of audit committee and the external audit quality. The presence of an audit committe (AUDCOM) is not mandatory in Tunisia context but recommended by the [46]. This variable is denoted by a dummy variable. The independence of audit committee (ACIND) is measured however by the proportion of not executive independent members within the committee. Finally, the external audit quality refers to the size and the reputation of auditor. With reference to Pittman and Fortin [12], we assess the auditor quality by his belonging to the major audit firms named (BIG 4).

\subsection{Econometric Specification}

We use OLS regression model estimated with robust standard errors to test empirically the effect of interaction of director board characteristics, ownership structure and external audit quality on the cost of debt of Tunisian listed companies.

We test the following regression model:

$$
\begin{aligned}
\mathrm{COD}_{i t}= & \alpha_{0}+\alpha_{1} \mathrm{BDSIZE}_{i t}+\alpha_{2} \mathrm{BDIND}_{i t}+\alpha_{3} \mathrm{BLOCK}_{i t}+\alpha_{4} \mathrm{MANAG}_{i t} \\
& +\alpha_{5} \mathrm{INSTIT}_{i t}+\alpha_{6} \mathrm{AUDCOM}_{i t}+\alpha_{7} \mathrm{ACIND}_{i t}+\alpha_{8} \mathrm{BIG}_{i t}+\alpha_{9} \mathrm{SIZE}_{i t} \\
& +\alpha_{10} \mathrm{ROA}_{i t}+\alpha_{11} \mathrm{LEV}_{i t}+\epsilon_{i t}
\end{aligned}
$$

where

COD: the cost of debt measured by the interest expense for firm $i$ and year $t$ divided by the short-term and long-term debts at the beginning of year $t$ for firm $i[1]$ and [43].

BSIZE: the board size. It represents the Number of director on the board.

BDIND: the Board independence. It refers to the proportion of independent directors on the board.

BLOCK: the presence of large shareholder holding more than $50 \%$ of the capital equity. This variable is measured by a dummy variable coded 1 .

MANAG: the presence of managers in the capital. This variable represents the proportion of capital equity detained by employees or managers.

INSTIT: the presence of institutional investor. This variable is measured by a dummy variable coded 1 .

AUDCOM: the presence of audit committee. This variable is measured by a dummy variable coded 1.

ACIND: the presence of independent member within the audit committee. It refers to the proportion of external director to total audit committee directors.

BIG4: Auditor belonging to the major audit firms named BIG 4. We attribute the note 1 if an audit report is signed by at least one auditor representing one of the Big 4 audit firms, and 0 otherwise.

The financial literature shows that other variables are likely to influence the decision of lenders when setting the loan interest rate and thus affect the cost of debt. 
We control for the firm performance or profitability as measured by the Return On Assets (ROA). Bhojraj and Sengupta, [5] document that less profitable firms support a very high default risk. Diamond and Verrecchia [14] attest that the profitability influences the relationship between disclosure and the cost of capital since the most profitable firms are more likely to disclose information and are likely to have a low cost of capital. Thus, the most successful firms are likely to overcome information asymmetries as they build more trust with their stakeholders and debtholders. Consequently, financial performance may decrease the cost of debt.

We also control for the size as measured by the natural logarithm of the firm's total assets (Size). Sharbati, Aslani and Barandagh [7] assert that large firms tend to be more diversified and are less exposed to bankruptcy risk than small firms. Hence, they may support a low cost of debt.

Finally, we consider the financial leverage (LEV) measured by the total debt to asset ratio. It represents the financial risk related to the company's business. According to [14], the cost of equity increases when financial leverage increases. The positive relationship between leverage and the cost of equity is also advanced by [15] and [11]. Consequently, the financial leverage may increase the cost of debt and reduce the firm's value.

\section{Result Analysis}

\subsection{Descriptive Statistics}

Table 1 exhibits the corporate governance traits and the audit quality. It reports that director board characteristics and ownership structure of Tunisian listed companies are consistent with those reported in previous studies [42] and [43], and the recommendation of the good behavior and governance report [46]. Specially, the mean value of the board size is around 8.7 and that $75 \%$ of the director member are independent. Table 1 shows also that $5 \%$ of Tunisian listed firms are managerial owned firms, $47.8 \%$ of companies on average, are held by block investors and that the percentage of institutional shareholders varies from $0 \%$ to $88 \%$. As regards to audit quality, the presence of a Big 4 among statutory auditors is found in $39.13 \%$ of the observations, and the existence of an audit committee in $82.16 \%$. Only $59 \%$ of these committees include independent directors, casting doubts about their monitoring power effectiveness. Finally, the leverage level for the sample is $47 \%$. This means that $47 \%$ of the total assets are financed by long-term debts.

\subsection{Variables Analysis}

Table 2 reports the Pearson pairwise correlations among the variables used in our empirical regressions. Table 2 indicates that the independent director board and the independent audit committee are strongly correlated at $51.6 \%$ at the significant level of $1 \%$. Moreover, we note the absence of correlation between the 
Table 1. Descriptive statistics.

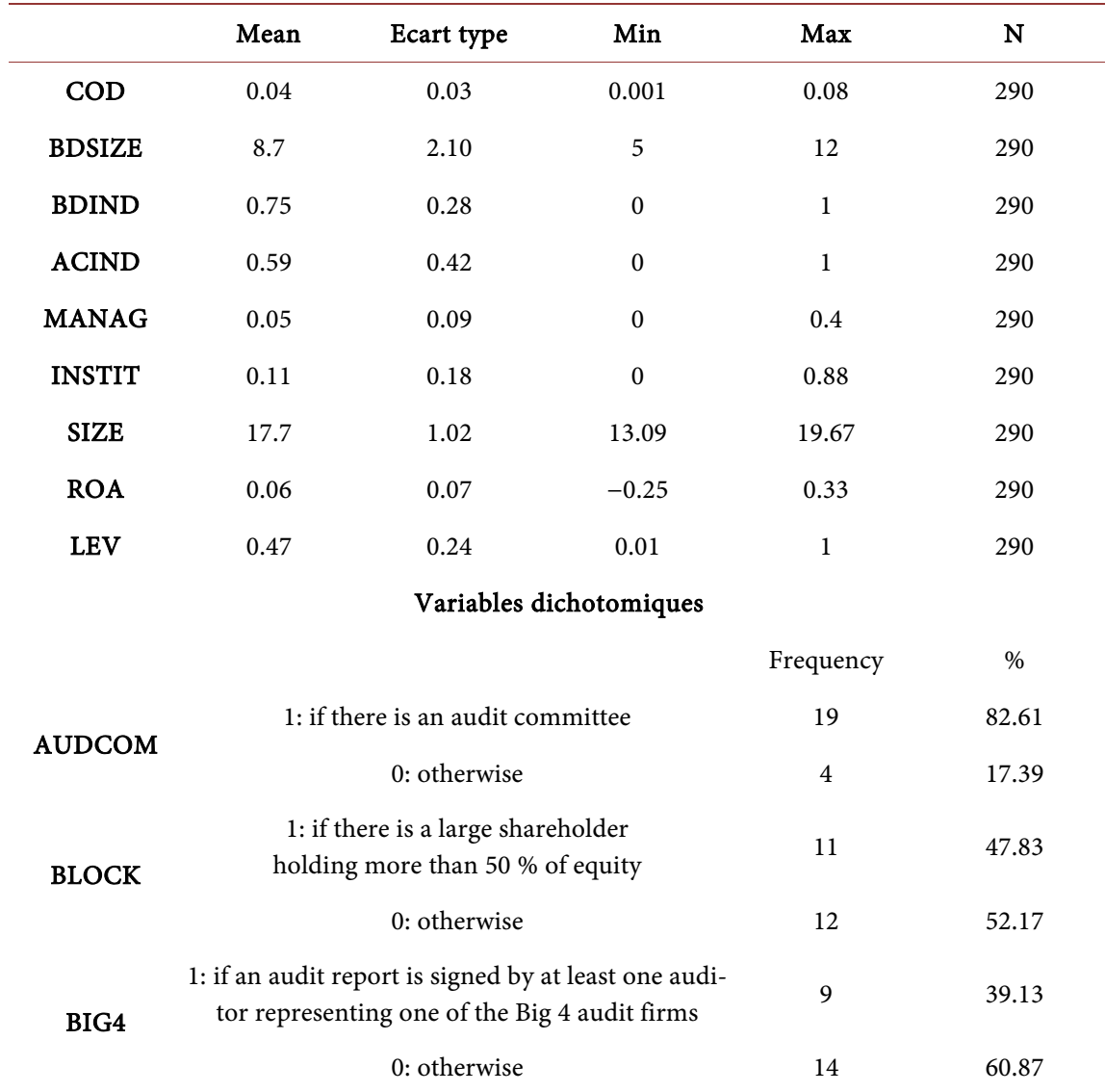

Notes: Table 1 exhibits descriptive statistics for a sample of 276 firm-year observations. COD is the interest expense for firm $i$ and year $t$ divided by the short-term and long-term debts. BSIZE represents the Number of director on the board. BDIND refers to the proportion of independent directors on the board. BLOCK: the presence of large shareholder holding more than $50 \%$ of the capital equity. MANAG: the presence of managers in the capital. INSTIT: the presence of institutional investor. AUDCOM: the presence of audit committee. ACIND: the presence of independent member within the audit committee. It refers to the proportion of external director to total audit committee directors. BIG4: Auditor belonging to the major audit firms named BIG 4. SIZE: the natural logarithm of the firm's total assets. LEV: the total debt to asset ratio. ROA: net income to total assets.

variables related to the director board characteristics and the ownership structure.

Table 2 computes also the variance Inflation Factor (VIF) to control for multi-colinearity of independent variables. The VIF tests indicate a values range between 1.1 and 1.82 below the level of 10 [47]. Hence, we confirm the inexistence of the multicollinearity issues.

The correlation matrix reports a negative correlation between financial leverage (LEV) and both the director board independence (BDIND) and the audit committee independence (ACIND). These two committees effectively oversee the decisions of the company, limiting thus the opportunistic actions of the managers.

Interestingly, the existence of an institutional shareholder (Instshlder) is negatively related $(-0.139)$ to financial leverage and positively $(0.367)$ to financial 
Table 2. Correlations matrix of Pearson and variance inflation factor (VIF).

\begin{tabular}{ccccccccc}
\hline & BDSIZE & BDIND & ACIND & MANAG & INSTIT & SIZE & ROA & LEV \\
\hline BDSIZE & 1 & & & & & & & \\
BDIND & -0.066 & 1 & & & & & & \\
ACIND & $0.269^{* *}$ & $0.516^{* *}$ & 1 & & & & & \\
MANAG & -0.037 & -0.023 & -0.038 & 1 & & & & \\
INSTIT & $-0.170^{* *}$ & -0.094 & 0.080 & -0.004 & 1 & & & \\
SIZE & $-0.129^{*}$ & $-0.196^{* *}$ & -0.086 & $0.167^{* *}$ & $0.155^{*}$ & 1 & & \\
ROA & -0.067 & 0.019 & $0.248^{* *}$ & 0.016 & $0.367^{* *}$ & $0.359^{* *}$ & 1 & \\
LEV & 0.085 & -0.077 & $-0.230^{* *}$ & $0.164^{* *}$ & $-0.139^{*}$ & -0.056 & $-0.455^{* *}$ & 1 \\
VIF & 1.82 & 1.69 & 1.65 & 1.64 & 1.50 & 1.43 & 1.31 & 1.10 \\
\hline
\end{tabular}

Notes: Table 2 displays the Pearson correlation matrix. COD is the interest expense for firm $i$ and year $t$ divided by the short-term and long-term debts. BSIZE represents the Number of director on the board. BDIND refers to the proportion of independent directors on the board. BLOCK: the presence of large shareholder holding more than $50 \%$ of the capital equity. MANAG: the presence of managers in the capital. INSTIT: the presence of institutional investor. AUDCOM: the presence of audit committee. ACIND: the presence of independent member within the audit committee. It refers to the proportion of external director to total audit committee directors. BIG4: Auditor belonging to the major audit firms named BIG 4. SIZE: the natural logarithm of the firm's total assets. LEV: the total debt to asset ratio. ROA: net income to total assets. ${ }^{* *}$, ${ }^{*}$ significance level respectively at $1 \%$ and $5 \%$.

performances. These results support the theoretical framework, which document that institutional investors has the ability to control the management through an effective monitoring process, actively oppose proposals that appear to be harmful to shareholders and vote more actively on antitakeover amendments than do other shareholders [32].

Finally, Table 2 shows that the Board independence and firm size are negatively correlated. This relation can be explained by the Tunisian setting specificity. Indeed, most Tunisian companies are family and concentrate downer ship firms, and are reluctant to the presence of independent or external directors on the board.

\subsection{Multivariate Analysis}

Table 3 reports the regression results. We firstly run the Breusch-Pagan test to measure the heteroscedasticity. We obtain then a significant statistic Fischer (prob $>\mathrm{F}=0.000$ ) that allows us to reject the null hypothesis and confirm the presence of heteroscedasticity problem. Secondly, the Wooldrigde test of intra-individual's auto correlation allow accepting null hypothesis (prob > F superior to 0.05), confirming thus the absence of auto correlation problem.

Table 3 shows that the Board size has a negative and significant effect on the cost of debt. This result supports the findings of [4] and argues that a large board may ensure the value relevance of financial statements. Investors of firms with larger boards believe that the financial accounting structures of those firms are better monitored, enabling those firms to decrease the cost of borrowing [4].

The findings also show that the Board composition has no significant effect on 
Table 3. Regression results.

\begin{tabular}{ccc}
\hline Variables & Coefficients & Student \\
\hline Constant & -4.497136 & 0.199 \\
BDSIZE & -1.145523 & $0.014^{*}$ \\
BDIND & -0.0711923 & 0.416 \\
AUDCOM & 0.0151796 & 0.811 \\
ACIND & 0.1243759 & 0.485 \\
BLOCK & -0.1114762 & $0.042^{*}$ \\
MANAG & 0.0442908 & 0.511 \\
INSTIT & 0.1722782 & $0.000^{* *}$ \\
BIG4 & -0.1770514 & $0.028^{*}$ \\
SIZE & 3.264705 & $0.002^{* *}$ \\
ROA & 0.0423597 & 0.371 \\
LEV & -0.1348752 & 0.327 \\
R 2 adjusted & 0.7567 & \\
Fischer & 3.12 & \\
Prob de F & 0.0006 & \\
N & 290 & \\
B & & \\
\hline & &
\end{tabular}

Notes: Table 3 reports regression results for a sample of 290 firm-year observations. COD is the interest expense for firm $i$ and year $t$ divided by the short-term and long-term debts. BSIZE represents the Number of director on the board. BDIND refers to the proportion of independent directors on the board. BLOCK: the presence of large shareholder holding more than $50 \%$ of the capital equity. MANAG: the presence of managers in the capital. INSTIT: the presence of institutional investor. AUDCOM: the presence of audit committee. ACIND: the presence of independent member within the audit committee. It refers to the proportion of external director to total audit committee directors. BIG4: Auditor belonging to the major audit firms named BIG 4. SIZE: the natural logarithm of the firm's total assets. LEV: the total debt to asset ratio. ROA: net income to total assets. ${ }^{*}$ significant at $5 \%$ level and ${ }^{* *}$ significant at $1 \%$ level.

the cost of debt. Debtholders suppose that the independent directors are not enough competent to control the managers and their presence in the board has no effect on the financial reporting quality [19].

The results point out that the presence of an audit committee has no effect on the cost of debt financing. Investors and banks think that internal audit committee (not supported by an external auditor) is unable to reduce the probability of earnings manipulation and lessening the managerial opportunism [41] and [44]. For this reason, they have no trust in audit committee and don't take in account this variable when determining the interest rate. This result is also confirmed even when there is an independent members within the audit committee. Consequently, the hypothesis arguing that audit committee independence is negatively related to the cost of debt is rejected.

Moreover, Table 3 relates that the presence of a blockholders has a negative and significant effect on the cost of debt financing. This finding corroborates the fact that firms with concentrated ownership structure may support a relatively low cost of debt. It invalidates the hypothesis assuming that controlling share- 
holders may exacerbate the agency problems and reduce the relevance of the financial information. The presence of blockholders in Tunisian lited firms may curb the discretionary behavior of the managers, incite them to adopt profitable strategies and disclose relevant and reliable information [28].

With respect to the presence of institutional shareholder, we note a significant and positive association with the cost of debt. The positive relation indicates that more the institutional shareholder is greater, more the cost of debt is high. In line with this finding, Bhojraj and Sengupta [5] attest that institutional investors do not have sufficient information on financial situation and do not play an effective role in monitoring the various policies that managers take in making decisions. Contrary to expected result, the presence of institutional shareholder creates incentives for managers to manage earnings upwards, enhancing thus the cost of debt.

Besides, the findings show that the managerial shareholders have non-significant effect on the cost of debt. So, we reject the hypothesis, which stipulates that the presence of managers-shareholders leads to an alignment effect of interest, maximizing thus the corporate value and reducing the cost of debt.

Furthermore, we find that the quality of external audit has a positive effect on the cost of debt. Tunisian firms audited by BIG4 support a heavy low cost debt comparing to firms audited by no BIG4. The auditor reputation or quality play an effective role in reducing the cost of debt of Tunisian listed companies. Banks and other debtholders suppose that the financial information is more reliable for BIG4 clients in comparison with other companies. They attest that the external audit quality can be an effective control mechanism to monitor the managers and guarantee the integrity of financial reports.

Finally, we note that the ROA has no effect on the cost of debt. We find the same result when using financial leverage. In debt economy such Tunisia setting, the cost of debt may be related to subjective criterion other than financial performance, such as political connection and favoritism. The interventionism of politicians and some influential people invalidate the linkage of the cost of debt to the financial performance. Indeed, firms with poor profitability may grant a low cost of debt only because the firm is held by an influential personality or well-known shareholders. At the same time, firms having high ROA may support illogically high cost of debt. Because banks are not numerous on the Tunisian market and firms are mainly financed by bank debt, these firms accept to pay high rates to fund their investment programs.

However, and surprisingly, the results show that the firm size is positively related to the cost of debt financing. Indeed, large companies support higher cost of debt comparing to small firms. Large companies are supposed to be more risky.

\section{Conclusions}

This paper investigates the effect of corporate governance practices and audit 
quality on the cost of debt of Tunisian listed companies over the period 2006-2016. From the agency view, debtholders support two risks: the expropriation risk and the information asymmetry. We suppose that the corporate governance effectiveness and the audit quality of borrowing firms may mitigate these risks. This, in turn, leads banks and other debtholders to reduce the risk premium, lowering thus the debt price requested. Our findings reveal that three governance traits exhibit a significant reducing effect on the cost of debt: the board size, the presence of block shareholder and auditor quality or reputation. First, investors believe that the large board may ensure the value relevance of financial statements of firms since their financial accounting structures are better monitored. Second, the presence of blockholders may curb the discretionary behavior of the managers, incite them to adopt profitable strategies and disclose relevant and reliable information. The ownership concentration may attenuate the agency problems and improve the relevance of the financial information. Third, the auditor reputation or quality play an effective role in reducing the cost of debt of Tunisian listed companies. Banks and other debtholders suppose that the financial information is more reliable for BIG 4 clients in comparison with other companies. They attest that the external audit quality can be an effective control mechanism to monitor the managers and guarantee the integrity of financial reports.

However, the results show that there is a significant and positive relation between the presence of institutional shareholders and the cost of debt. Banks and debtholders believe that the presence of institutional shareholder creates incentives for managers to manage earnings upwards. As they do not have sufficient information on financial situation, they are unable to play an effective role in monitoring the various policies that managers take in making decisions.

With respect to the managerial sharholders, the findings attest that the presence of managers-shareholders does not lead neither to an alignment effect of interest nor to a maximization of the corporate value. The presence of managerial shareholders has no significant effect on the cost of debt.

Furthermore, the findings point out that the board composition has no significant effect on the cost of debt. Debtholders suppose that the independent directors are not enough competent to control the managers and their presence in the board has no effect on the financial reporting quality. The results also reveal that investors and banks think that internal audit committee (not supported by an external auditor) is unable to reduce the probability of earnings manipulation and lessening the managerial opportunism. They do not consider the audit committee as playing a key role in supervising the opportunism behavior of managers and reducing risks. This result is also confirmed even when there is an independent member within the audit committee.

Finally, the results show that the firm size is positively related to the cost of debt financing. Indeed, large companies support higher cost of debt comparing to small firms because they are supposed to be more risky. The financial performance and the financial leverage have no effect on the cost of debt. In Tunisian 
setting, the cost of debt determinants may be based on subjective criterion other than corporate financial performance such as political connection and favoritism.

Firms with poor profitability may grant a low cost of debt only because the firm is held by an influential personality or well-known shareholders. In the same time, firms having high profitability may support illogically high cost of debt. The board supervision ineffectiveness failure and the audit committee inefficiency may encourage such behaviors. The results are very interesting in Tunisian context. The study helps banks and creditors to more comprehensively evaluate the effectiveness of the corporate governance mechanism. It also encourages managers to consider audit quality as a means to improve the opacity risk the reputational capital, lowering thus the cost of debt.

Future research may extend our findings by examining the relationship between the political connection of shareholders and the cost of debt.

\section{Conflicts of Interest}

The author declares no conflicts of interest regarding the publication of this paper.

\section{References}

[1] Sengupta, P. (1998) Corporate Disclosure Quality and the Cost of Debt. The Accounting Review, 73, 459-474.

[2] Ertugrul, M. and Hegde, S. (2008) Board Compensation Practices and Agency Cost of Debt. Journal of Corporate Finance, 14, 512-531.

[3] Schauten, M. and Van Dijk, D.J.C. (2010) Corporate Governance and the Cost of Debt of Large European Firms. ERIM Report Series Reference No. ERS-2010-025-F \& A. https://ssrn.com/abstract $=1620719$

[4] Anderson, R.C., Mansi, S.A. and Reeb, D.M. (2004) Board Characteristics, Accounting Report Integrity, and the Cost of Debt. Journal of Accounting and Economics, 37, 315-342. https://doi.org/10.1016/j.jacceco.2004.01.004

[5] Bhojraj, S. and Sengupta, P. (2003) Effect of Corporate Governance on Bond Ratings and Yiels: The Role of Institutional Investors and Outside Directors. Journal of Business, 76, 455-475. https://doi.org/10.1086/344114

[6] Feki A. and Khoufi W. (2008) L'effet des caractéristiques du conseil d'administration et de la qualité de l'information financière sur le coût de la dette (Cas des entreprises industrielles françaises). La comptabilité, le contrôle et l'audit entre changement et stabilité, France.

[7] Sharbati, A., Aslani, A. and Barandagh, M.I. (2014) Corporate Governance and the Cost of Debt Financing at Listed Companies in Teheran Stock Exchange. International Journal of Accounting Research, 1, 24-29.

[8] Hashim, H.A. and Amrah, M. (2016) Corporate Governance Mechanisms and Cost of Debt: Evidence of Family and Non-Family Firms in Oman. Managerial Auditing Journal, 31, 314-336. https://doi.org/10.1108/MAJ-12-2014-1139

[9] Ghouma H., Ben-Nasr, H. and Yana, R. (2018) Corporate Governance and Cost of Debt Financing: Empirical Evidence from Canada. The Quarterly Review of Economics and Finance, 67, 138-148. https://doi.org/10.1016/j.qref.2017.06.004

[10] Adam, M., Mukhtaruddin, M., Soraya, N. and Yusrianti, H. (2015) Good Corporate 
Governance and Cost of Debt: Listed Companies on Indonesian Institute for Corporate Governance. Asian Social Science, 11, 58-77. https://doi.org/10.5539/ass.v11n25p58

[11] Armstrong, C., Core, J., Taylor, D. and Verrecchia, R. (2011) When Does Information Asymmetry Affect the Cost of Capital. Journal of Accounting Research, 49, 1-40. https://doi.org/10.1111/j.1475-679X.2010.00391.X

[12] Pittman, J.A. and Fortin, S. (2004) Auditor Choice and the Cost of Debt Capital for Newly Public Firms. Journal of Accounting and Economics, 37, 113-136. https://doi.org/10.1016/j.jacceco.2003.06.005

[13] Piot, C. and Janin, R. (2007) External Auditors, Audit Committees and Earnings Management in France. The European Accounting Review, 16, 429-454. https://doi.org/10.1080/09638180701391030

[14] Diamond, D. and Verrecchia, R. (1991) Disclosure, Liquidity, and the Cost of Capital. The Journal of Finance, 46, 1325-1359. https://doi.org/10.1111/j.1540-6261.1991.tb04620.x

[15] Bharath, S., Pasquariello, P. and Wu, G. (2009) Does Asymmetric Information Drive Capital Structure Decisions? Review of Financial Studies, 22, 3211-3243. https://doi.org/10.1093/rfs/hhn076

[16] Petra, S.T. (2007) The Effects of Corporate Governance on the Informativeness of Earnings. Economics of Governance, 8, 129-152. https://doi.org/10.1007/s10101-006-0018-8

[17] Bradley, M. and Chen, D. (2011) Corporate Governance and the Cost of Debt: Evidence from Director Limited Liability and Indemnification Provisions. Journal of Corporate Finance, 17, 83-107. https://doi.org/10.1016/j.jcorpfin.2010.08.001

[18] Elmagrhi, M.H., Ntim, C.G., Wang, Y., Abdou, H.A. and Zalata, A.M. (2018) Corporate Governance Disclosure Index-Executive Pay Nexus: The Moderating Effect of Governance Mechanisms. European Management Review, 54. https://doi.org/10.1111/emre.12329

[19] Bradbury, M., Mak, Y. and Tan, S. (2006) Board Characteristics, Audit Committee Characteristics and Abnormal Accruals. Pacific Accounting Review, 18, 47-68. https://doi.org/10.1108/01140580610732813

[20] Ballesta, P. and Meca, E. (2007) Ownership Structure, Discretionary Accruals and the Informativeness of Earnings. Corporate Governance, 15, 677-691. https://doi.org/10.1111/j.1467-8683.2007.00596.x

[21] Allegrini, M. and Greco, G. (2013) Corporate Boards, Audit Committees and Voluntary Disclosure: Evidence from Italian Listed Companies. Journal of Management and Governance, 17, 187-216. https://doi.org/10.1007/s10997-011-9168-3

[22] Klein, A. (2002) Audit Committee, Board of Director Characteristics, and Earnings Management. Journal of Accounting and Economics, 33, 375-400. https://doi.org/10.1016/S0165-4101(02)00059-9

[23] Samaha, K., Khlif, H. and Hussainey, K. (2015) The Impact of Board and Audit Committee Characteristics on Voluntary Disclosure: A Meta-Analysis. Journal of International Accounting, Auditing and Taxation, 24, 13-28. https://doi.org/10.1016/j.intaccaudtax.2014.11.001

[24] Beekes, W., Pope, P. and Young, S. (2004) The Link between Earnings and Timeliness, Earnings Conservatism and Board Composition: Evidence from the UK. Corporate Governance: An International Review, 12, 14-59. https://doi.org/10.1111/j.1467-8683.2004.00342.x 
[25] Firth, M., Fung, P., and Rui, O. (2007) Ownership, Two-Tier Board Structure, and the Informativeness of Earnings: Evidence from China. Journal of Accounting and Public Policy, 26, 463-496. https://doi.org/10.1016/j.jaccpubpol.2007.05.004

[26] Dimitropoulos, P. and Asteriou, D. (2010) The Effect of Board Composition on the Informativeness and Quality of Annual Earnings: Empirical Evidence from Greece. Research in International Business and Finance, 24, 190-205. https://doi.org/10.1016/j.ribaf.2009.12.001

[27] Badertscher, B.A., Givoly, D., Katz, S.P. and Lee, H. (2018) Private Ownership and the Cost of Public Debt: Evidence from the Bond Market. Management Science, 65, 450-457. https://doi.org/10.1287/mnsc.2017.2935

[28] Shleifer, A. and Vishny R.W. (1997) A Survey of Corporate Governance. Journal of Finance, 52, 737-783. https://doi.org/10.1111/j.1540-6261.1997.tb04820.x

[29] Jensen, M.C. and Meckling, W.H. (1976) Theory of the Firm: Managerial Behavior, Agency Costs and Ownership Structure. Journal of Financial Economics, 3, 305-360. https://doi.org/10.1016/0304-405X(76)90026-X

[30] Patelli, L. and Prencipe, A. (2007) The Relationship between Voluntary Disclosure and Independent Directors in the Presence of a Dominant Shareholder. European Accounting Review, 16, 5-33. https://doi.org/10.1080/09638180701265820

[31] Martinez Ferrero, J. Rodríguez-Ariza L. and Bermejo-Sánchez M. (2016) Is Family Ownership of a Firm Associated with the Control of Managerial Discretion and Corporate Decisions? Journal of Family Business Management, 6, 23-45. https://doi.org/10.1108/JFBM-06-2015-0022

[32] Aggarwal, R., Erel, I., Ferreira, M. and Matos, P. (2011) Does Governance Travel around the World? Evidence from Institutional Investors. Journal of Financial Economics, 100, 154-181. https://doi.org/10.1016/j.jfineco.2010.10.018

[33] Jiambalvo, J., Rajgopal, S. and Venkatachalam, M. (2002) Institutional Ownership and the Extent to Which Stock Prices Reflect Future Earnings. Contemporary Accounting Research, 19, 117-145. https://doi.org/10.1506/EQUA-NVI9-E712-UKBI

[34] Florackis, C.H. and Kostakis, A. (2015) Dividend Policy, Managerial Ownership and Debt Financing: A Non-Parametric Perspective. European Journal of Operational Research, 241, 783-795. https://doi.org/10.1016/j.ejor.2014.08.031

[35] Chen, Y.W., Knechel, R., Marisetty, V.B., Truong, C. and Veeraraghavan, M. (2017) Board Independence and Internal Control Weakness: Evidence from SOX 404 Disclosures. Auditing. A Journal of Practice \& Theory, 36, 45-62. https://doi.org/10.2308/ajpt-51577

[36] Zgarni, I. and Khamoussi, H. (2016) Audit Committee Effectiveness, Audit Quality and Earnings Management: A Meta-Analysis. International Journal of Law and Management, 58, 179-196. https://doi.org/10.1108/IJLMA-01-2015-0006

[37] Sultana, N. and Singh, H.J.M. (2014) Audit Committee Characteristics and Audit Report Lag. International Journal of Auditing, 19, 72-87. https://doi.org/10.1111/ijau.12033

[38] Tepalagul, N. and Lin, L. (2015) Auditor Independence and Audit Quality: A Literature Review. Journal of Accounting, Auditing \& Finance, 30, 101-121. https://doi.org/10.1177/0148558X14544505

[39] Cadbury, A. (1992) Report of the Committee on the Financial Aspects of Corporate Governance. Gee \& Co. Ltd., London.

[40] BRC (1999) Blue Ribbon Committee (BRC) on Improving the Effectiveness of Corporate Audit Committees. Stamford, CT. 
[41] DeAngelo, L.E. (1981) Auditor Size and Audit Quality. Journal of Accounting and Economics, 3, 183-199. https://doi.org/10.1016/0165-4101(81)90002-1

[42] Kouaib, A. and Jarboui, A. (2014) External Audit Quality and Ownership Structure: Interaction and Impact on Earnings Management of Industrial and Commercial Tunisian Sectors. Journal of Economics, Finance and Administrative Science, 19, 78-89. https://doi.org/10.1016/j.jefas.2014.10.001

[43] Achek, I. and Gallali, M.I. (2015) Audit Quality, Timely Disclosure and the Cost of Debt: Tunisian Evidence. Journal of Modern Accounting and Auditing, 11, 194-209. https://doi.org/10.17265/1548-6583/2015.04.002

[44] Kim, J.-B., Chung, R. and Firth, M. (2003) Auditor Conservatism, Asymmetric Monitoring and Earnings Management. Contemporary Accounting Research, 20, 323-359. https://doi.org/10.1506/J29K-MRUA-0APP-YJ6V

[45] Brown, F. and Knechel, W.F. (2016) Auditor-Client Compatibility and Audit Firm Selection. Journal of Accounting Research, 54, 725-775. https://doi.org/10.1111/1475-679X.12105

[46] European Bank for Reconstruction and Development (2017) Corporate Governance in Transition Economies Tunisia Country Report, 17p.

[47] Neter, J., Kutner, M.H., Nachtsheim, C.J. and Wasserman, W. (1996) Applied Linear Statistical Models. 4th Edition, Richard D. Irwin, Chicago, IL. 